Vol. 18, $n^{\circ} 1 \mid 2014$

Varia

\title{
Jonathan Dunnage, Mussolini's Policemen : Behaviour, ideology and institutional culture in representation and practice
}

Manchester, Manchester University Press, 2012, 239 pp., ISBN 97807190

81392.

Clive Emsley

\section{(2) OpenEdition}

\section{Journals}

Electronic version

URL: http://journals.openedition.org/chs/1622

DOI: $10.4000 /$ chs. 1622

ISSN: 1663-4837

Publisher

Librairie Droz

Printed version

Date of publication: 1 July 2014

Number of pages: 159-160

ISBN: 978-2-600-01935-4

ISSN: 1422-0857

\section{Electronic reference}

Clive Emsley, « Jonathan Dunnage, Mussolini's Policemen : Behaviour, ideology and institutional culture in representation and practice », Crime, Histoire \& Sociétés / Crime, History \& Societies [Online], Vol. 18, $n^{\circ} 11$ 2014, Online since 17 June 2016, connection on 22 September 2020. URL : http:// journals.openedition.org/chs/1622; DOI : https://doi.org/10.4000/chs.1622

This text was automatically generated on 22 September 2020

(C) Droz 


\section{Jonathan Dunnage, Mussolini's Policemen : Behaviour, ideology and institutional culture in representation and practice}

Manchester, Manchester University Press, 2012, 239 pp., ISBN 97807190

81392.

Clive Emsley

\section{REFERENCES}

Jonathan Dunnage, Mussolini's Policemen : Behaviour, ideology and institutional culture in representation and practice, Manchester, Manchester University Press, 2012, 239 pp., ISBN 9780719081392.

1 What provides a police institution with its culture, its vision of how to behave, its awareness of the society in which it functions? And how far can a significant shift in a country's style and system of government affect police attitudes and behaviour? These are the underlying questions at the heart of Jonathan Dunnage's important new study of Mussolini's policemen. The policemen in Dunnage's book are mainly those of the Interior Ministry. They have never had the military glamour of the Carabinieri and, unlike this gendarmerie-style force, never acquired battle honours during the Risorgimento. In the history of Fascist Italy they have been overshadowed by the fascination with secret, political police - OVRA, the Opera Vigilanza e Repressione dell'Anti- fascismo and the Interior Ministry's own POLPOL, the Divisione Polizia Politica. Dunnage's policemen were those responsible for the day-to-day, largely unglamorous policing tasks of crime prevention and detection, but with some public order and political requirements thrown in. In Liberal Italy they were poorly paid and resourced, served out of shabby police stations, and were generally poorly regarded by the 
population. It is understandable that, overall, they would favour a regime that promised to improve their lot and give them wider powers for their tasks.

Drawing significantly on the personnel files of many middle-ranking officers in the police Dunnage explores the recruitment, training and work practice of the ordinary Ministry of Interior Police across the Fascist period. Mussolini's regime boasted of modernising the practices of the Italian state with the aim of sweeping away the inefficiencies of the old Liberal regime. A few of the police were 'firsthour fascists' who had supported the movement before Mussolini came to power; towards the end of the 1930s most of the recruits had been educated and brought up under Fascist rule and, unsurprisingly, joined the police with something of a Fascist ideology. Membership of the Party was obligatory from 1932 and of the fascist employee association from 1937. But, Dunnage concludes, whether this all led to a 'fascistisation' of the police remains a moot point and, unquestionably, much of the old system remained - not least the rivalry between the Interior Ministry Police and the proud, military Carabinieri. There were a few policemen who clearly subscribed to the most extreme elements of Fascist ideology and co-operated earnestly and whole-heartedly with the Nazis in German occupied Italy after Mussolini's initial ejection in 1943. The prestige, power and technology of the police were emphasised in iconography and in the national celebration, the Festa della Polizia, held annually on 18 October from 1928. Yet some men used their membership of the Party for their own ends, which appears little different from the clientelism of the old Liberal period. At the same time, the Ministry had little interest in men who stressed their long-term Party affiliations but were inefficient, idle or just useless; while on the ground several relatively senior police officers had no qualms about challenging senior figures in the local Party and arresting members of the Party whose political zeal led them to break the law. As Italy became a battleground and the conflict between the Axis and the Allies became an Italian civil war, some police deserted to the partisans while others attempted to keep their posts in the gradually diminishing Fascist state at the same time as they assisted anti-Fascists, Jews and other Fascist victims, and made links with the partisans. Dunnage does his best to untangle the careers of men in these circumstances. But, as he is at pains to point out, the truth behind much of what went on often seems difficult to assess because of the confusing evidence left in the personnel files, especially those of policemen who continued to serve in the post-World War era. It is interesting to note that personnel files do not appear to have been made available to the commission that investigated charges against police officers after the war.

Dunnage has produced a well-researched, well-argued and thought-provoking monograph that fills and important gap in our knowledge and challenges some longestablished assumptions. There is, perhaps, one minor omission. While there is much here on the police in the German dominated Italian Social Republic, there is very little about how Mussolini's police in the south of Italy responded when an allied bridgehead was established and expanded from 1943. The allied forces faced massive problems of goods disappearing from docks and in transit and they had to work with the Italian police to pursue these thefts and to control the burgeoning black market. There was also an allied police mission, led by Arthur Young who had been the youngest chief constable in England. Young's command, made up of British Bobbies, followed the allied armies up the boot intent on reshaping the Italian Police in a democratic mould. From Dunnage's description of the way in which the postwar Italian Police - often led 
by men who had learnt their trade under Mussolini - continued many of the policies and practices of the fascist period, Young's mission had little success. And this brings us back to the questions outlined at the head of this review.

\section{AUTHORS}

\section{CLIVE EMSLEY}

The Open University 